\title{
Shell dissolution observed in Limacina helicina antarctica from the Ross Sea, Antarctica: paired shell characteristics and in situ seawater chemistry
}

5 Kevin M. Johnson ${ }^{1}$, Umihiko Hoshijima ${ }^{1}$, Cailan S. Sugano' ${ }^{1}$, Alice T. Nguyen ${ }^{1}$ and Gretchen E. Hofmann ${ }^{1}$

Department of Ecology, Evolution and Marine Biology, University of California, Santa Barbara, Santa Barbara CA 93106-9620 USA

Correspondence to: Gretchen E. Hofmann (gretchen.hofmann@lifesci.ucsb.edu)

Abstract. The euthecosome (shelled) Antarctic pteropod, Limacina helicina antarctica, is a dominant member of the Southern Ocean macrozooplankton community, and due to its aragonitic shell, is thought to be particularly vulnerable to ocean acidification and undersaturation conditions that are predicted in the future. Notably, pteropods in surface waters and

15 near the continental shelf in the Ross Sea are highly vulnerable as these regions are predicted to be seasonally under-saturated within 2-3 decades. Carbonate chemistry data are rare for this region and here we present the results of a 6-week field study and report patterns of dissolution of juvenile pteropods along with carbonate chemistry of seawater at the time of collection. Conducted in McMurdo Sound in the south Ross Sea in the Pacific sector of the Southern

20 Ocean, L. h. antarctica was successfully collected in plankton tows through the fast sea ice at a single station at $50 \mathrm{~m}$. During the 6-week field study, ocean $\mathrm{pH}$ was relatively stable, ranging from 7.988 in October to 8.029 by early December. Calculated saturation states for aragonite $\left(\Omega_{\text {arag }}\right)$ over the 6-week study period ranged from 1.16 to 1.24 . Pteropods collected at each sampling time point were prepared for SEM and analysis revealed that roughly $63 \%$ of the shells

25 displayed some degree of shell irregularities suggesting that active dissolution of the aragonitic shell was ongoing under in situ conditions. These results add to the accumulating evidence that shelled pteropods of the Southern Ocean are experiencing aragonite under-saturation events in the present-day that lead to a majority of individuals displaying shell dissolution. Predicted changes to the carbonate system in the Southern Ocean from ocean acidification will likely 
Biogeosciences Discuss., doi:10.5194/bg-2016-467, 2016

Manuscript under review for journal Biogeosciences

Published: 22 November 2016

(c) Author(s) 2016. CC-BY 3.0 License.

expand the intensity and duration of these under-saturation events, increasing the need to better understand how pteropods will fare in response to ocean acidification.

Keywords: Limacina helicina antarctica, pteropod, ocean acidification, Ross Sea, pH, Southern

5

\section{Introduction}

The uptake of anthropogenic $\mathrm{CO}_{2}$ by the surface ocean, a process known as ocean acidification, is reducing the $\mathrm{pH}$ and carbonate mineral saturation state of seawater at an unprecedented rate ((Feely et al., 2004;Fabry et al., 2009; Orr et al., 2005). The euthecosome (shelled) pteropods, such as Limacina helicina, precipitate a comparatively soluble form of calcium carbonate (aragonite), leading to increased sensitivity to changes in carbonate chemistry (Bednaršek et al., 2012a;Fabry, 1989). Recently, pteropods in the Limacina complex

15 have been identified as organisms that are highly vulnerable to ocean acidification and thus may serve as an indicator organism for trajectories of change in high latitude marine ecosystems (Fabry et al., 2009;Bednaršek et al., 2016a;Comeau et al., 2009; Lischka et al., 2011). In this study, we report on the results of a field study in McMurdo Sound in the Pacific sector of the Southern Ocean where shelled Antarctic pteropods, Limacina helicina antarctica, were collected during the 2014 austral summer. In presenting paired organismal data and in situ measurements of $\mathrm{pCO}_{2}$ at the time of collection, this study illustrates how present-day carbonate chemistry may present a challenge to biogenic calcification in the Antarctic pteropod, L. h. antarctica.

The Southern Ocean is predicted to be first in time to experience changes in carbonate chemistry due to ocean acidification (McNeil and Matear, 2008;Fabry et al., 2009;Orr et al., 2005; Hauri et al., 2015). Recent modeling efforts in the Southern Ocean have underscored the extent to which aragonite undersaturation events are occurring and will occur due to ocean acidification. Hauri et al. (2015) used a suite of Earth system models to forecast that by the year 2100 , surface waters in the Southern Ocean will be undersaturated with respect to aragonite for 30 six months out of the year. In McMurdo Sound, Kapsenberg et al. (2015) conducted a detailed 
Biogeosciences Discuss., doi:10.5194/bg-2016-467, 2016

Manuscript under review for journal Biogeosciences

Published: 22 November 2016

(c) Author(s) 2016. CC-BY 3.0 License.

investigation into the near-shore Antarctic carbonate chemistry system using autonomous $\mathrm{pH}$ sensors and proposed that McMurdo Sound may experience under-saturation during the austral winter by the year 2030. With increasing anthropogenic $\mathrm{CO}_{2}$ levels, the saturation state of calcium carbonate minerals in many marine ecosystems is decreasing, thereby challenging

5 calcification in a number of species (Hofmann et al., 2010). With shells composed entirely of aragonite, pteropods in the Limacina complex may act as sentinel organisms for the impacts of ocean acidification (Bednaršek et al., 2014a;Bednaršek et al., 2016b;Peck et al., 2015).

Although pteropods are held up as bioindicators of future change in ocean chemistry, recent assessments using scanning electron microscopy (SEM) of Limacina spp. in the Eastern

10 Pacific and Southern Ocean suggest that shell dissolution, driven by seasonal patterns of upwelling in coastal regions, are already occurring (Bednaršek et al., 2012; Bednaršek et al., 2014). With regard to $L$. $h$. antarctica, investigators have detected shell dissolution in recently collected field samples (Bednaršek et al., 2012). Although there is some suggestion that these dissolution patterns only occur when the protective outer organic layer (i.e., the periostracum)

15 has been breached by some physical process (Peck et al., 2015). Nevertheless, pteropod shells are composed of aragonite, a comparatively soluble form of calcium carbonate (Andersson et al., 2008), and likely susceptible to dissolution in nature when exposed to undersaturated seawater (Bednaršek et al., 2014b;Fabry et al., 2008;Fabry et al., 2009). Although researchers have made shipboard collections and analyzed preserved shells of Limacina from the Antarctic, few studies have examined the integrity of the shell when specimen collection is paired with in situ seawater chemistry. Further, given the scarcity of data on the seawater chemistry of nearshore polar waters (Schram, 2015;Kapsenberg et al., 2015), there is a discrepancy in our understanding of the current conditions that $L . h$. antarctica encounters in the water column.

In this light, the goal of this study was threefold: (i.) to collect pteropods in the field and determine the $\mathrm{pH}$ and saturation state of the seawater at the time of collection in the austral summer, (ii.) to describe basic organismal and ecological traits such as size and abundance of the collections, and (iii.) use SEM to assess patterns of shell conditions in collected specimens. These analyses are the first extended pteropod sampling effort aimed at capturing the combined natural variability of seawater chemistry and shell conditions in Antarctic pteropods. The 
Biogeosciences Discuss., doi:10.5194/bg-2016-467, 2016

Manuscript under review for journal Biogeosciences

Published: 22 November 2016

(c) Author(s) 2016. CC-BY 3.0 License.

results from this study add to a growing body of literature that highlights pteropods as sentinel organisms of ocean acidification.

\section{Materials and methods}

5

\subsection{Field sampling of pteropods}

Juvenile pteropods (Limacina helicina antarctica) were collected through the sea ice in McMurdo Sound in the southern Ross Sea during the austral spring and summer, from OctoberDecember 2014. Pteropod collections were performed at a depth of $50 \mathrm{~m}$ via plankton tows performed by hand at a rate of approximately $2.4 \mathrm{~m} \mathrm{~s}^{-1}$, with a small collapsible plankton net (100 $\mu \mathrm{m}$ mesh) designed specifically to be deployed through small-diameter holes drilled through the sea ice (Sewell, 2005). Plankton tows were performed at least twice per week at a

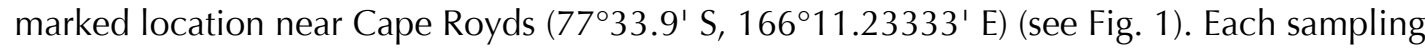
event consisted of three consecutive tows to $50 \mathrm{~m}$. For each tow, the number of $L$. $h$. antarctica were individually enumerated and field densities were then calculated by dividing the total number of pteropods by the total volume of water sampled (Hunt et al., 2008). Water chemistry samples were taken following the recovery of every tow at a depth of $50 \mathrm{~m}$ using a Niskin sampler, transported back to McMurdo station, and immediately preserved with saturated mercuric chloride according to Dickson et al. (2007).

\subsection{Post-collection handling}

After collection, pteropods were maintained in ambient seawater $\left(-1.9^{\circ} \mathrm{C}\right)$ in $500 \mathrm{ml}$ Nalgene containers, and immediately transported to the McMurdo laboratory facilities. Animals from each collection were counted in order to estimate catch effort. To prepare samples for morphological measurements and scanning electron microscopy (SEM), pools of 10 pteropods were incubated in $50 \%$ ethanol overnight at $+4{ }^{\circ} \mathrm{C}$ and then transferred to $70 \%$ ethanol and stored at $+4{ }^{\circ} \mathrm{C}$. 
Biogeosciences Discuss., doi:10.5194/bg-2016-467, 2016

Manuscript under review for journal Biogeosciences

Published: 22 November 2016

(c) Author(s) 2016. CC-BY 3.0 License.

\subsection{Methodology for scanning electron microscopy}

Scanning electron micrographs were obtained for closer examination of shell surface conditions at five collection time points that spanned the 6-week study period. To remove abiogenic

5 crystals from the shell surface, pteropod samples were gently rinsed with fresh $70 \%$ ethanol twice followed by a brief rinse in $95 \%$ ethanol. Samples were subsequently air-dried before using fine brushes to carefully position shells in the apical view on aluminum stubs mounted with adhesive carbon conductive tape. To avoid causing structural damage to the apical side of the shell (i.e., the side that was imaged), specimens were positioned using two fine brushes that

10 only came into contact with the basal side of the shell. Mounted specimens were then sputtercoated with gold/palladium for 90 seconds and imaged with a FEI Inspect S Electron Scanning Microscope at the Microscopy and Microanalysis Facility of the Materials Research Laboratory (MRL) Shared Experimental Facilities located at UC Santa Barbara.

\section{$15 \quad 2.4$ Analysis of shell dissolution}

Semi-quantitative analysis of shell dissolution was performed using the same language and patterns of dissolution as described in Bednaršek et al. (2012b). We categorized three types of dissolution that are reported as minor (Type 1), moderate (Type 2), and severe (Type 3) (see

20 Fig. 6). The analysis also scored shells without signs of shell irregularities as a Type 0 pattern. To standardize the total area of the shell analyzed between individuals, percent cover of each dissolution type was measured over the protoconch region of each shell using SEM imagery and the program Image $(1.49 \mathrm{v})$. Percent cover data of each dissolution type was compared within tows using a Kurksal - Wallis test and a Dunn test of multiple comparisons was used to test for

25 differences between tows (Bednaršek et al., 2012c). The number of shells analyzed and corresponding date of field collection is as follows: tow 2 on November $4(n=11)$; tow 7 on November $18(n=11)$; tow 8 on November $22(n=7)$; tow 9 on November $24(n=10)$; and tow 14 on December $8(n=12)$. 
Biogeosciences Discuss., doi:10.5194/bg-2016-467, 2016

Manuscript under review for journal Biogeosciences

Published: 22 November 2016

(c) Author(s) 2016. CC-BY 3.0 License.

For each tow, 30 individuals were imaged using a Cannon Powershot A630 mounted on a Wild M37Z stereomicroscope for morphological measurements. To estimate size, shell diameter was measured along a line $90^{\circ}$ from the apex of the protoconch to the edges of the shell on a flat-lying specimen (Fig. 2).

5

\subsection{Carbonate chemistry}

Seawater chemistry was performed on samples collected form the field at the McMurdo Station Crary Laboratory. Bottle samples, collected in borosilicate bottles, were preserved with saturated mercuric chloride immediately upon arrival at McMurdo Station, and subsequently

10 stored at $+4{ }^{\circ} \mathrm{C}$ until analyzed as described in Standard Operating Procedure 1 (SOP1) (Dickson et al., 2007). From each sample, pH was measured using the m-cresol (SigmaAldrich ${ }^{\circledR}$ ) spectrophotometric method described in SOP 6b (Dickson et al., 2007). Salinity was measured using a calibrated YSI 3100 conductivity probe and total alkalinity measurements were conducted using open-cell titration method (SOP3b) with a Mettler-Toledo T50 (Dickson

15 et al., 2007). To calculate field pH and aragonite saturation states, the computer software $\mathrm{CO} 2 \mathrm{Calc}$ was used with the in situ temperature estimated to be $-1.9{ }^{\circ} \mathrm{C}$ based on multi-year $\mathrm{pH}$ and temperature time-series data (Kapsenberg et al., 2015; Robbins et al., 2010).

\section{Results}

\section{3.1 Pteropod collections}

Pteropods were collected at a study site near Cape Royds for approximately six weeks, from October $31^{\text {th }}$-December $8^{\text {th }} 2014$ (Fig. 1). Plankton towing at this location began on October 29th, with the first collection of pteropods occurring on October 31. L. h. antarctica individuals were consistently collected from that date until the last tow on December 8th, 2014

25 (a date that was set by the closing of the sea ice near McMurdo Station).

Over the collection period, L. h. antarctica densities ranged from $3-81$ individuals $\mathrm{m}^{-3}$ and reached peak abundances between November $11^{\text {th }}$ and November $24^{\text {th }}$ (Fig. 3). Body size of L. h. antarctica ranged from $0.484 \mathrm{~mm}-1.54 \mathrm{~mm}$ and were distributed amongst three distinct size classes: $0.84 \pm 0.09 \mathrm{~mm}, 1.01 \pm 0.15 \mathrm{~mm}$, and $1.19 \pm 0.14 \mathrm{~mm}$; Tukey's Honestly

30 Significant Difference (HSD) test (adjusted p-value < 0.05) (Fig. 4). 


\subsection{Paired in situ carbonate chemistry}

Over the course of the collection period, carbonate chemistry remained relatively stable with slight changes towards the end of the 6-week period (Fig. 5). Average pH for Cape Royds seawater samples on October $31^{\text {st }}$ was $7.988 \pm 0.003$, and increased to $8.029 \pm 0.003$ by

5 December $5^{\text {th }}, 2014$. The aragonite saturation state of the seawater $\left(\Omega_{\text {arag }}\right)$ on October $31^{\text {st }}$ was $1.159 \pm 0.0067$ and increased to $1.239 \pm 0.002$ by December $5^{\text {th }}, 2014$. Overall, by December, Cape Royds had experienced a decrease in $\mathrm{pCO}_{2}$ of $41 \mu \mathrm{atm}$ and a modest increase in $\Omega_{\text {arag }}$ of 0.08. A complete list of carbonate chemistry for each sampling event is shown in Table 1.

\section{$10 \quad 3.3$ Shell characteristics and dissolution patterns}

Dissolution was observed in a majority of pteropods shells from all collection periods. The spatial extent of this damage, classified by varying degrees of dissolution (illustrated in Fig. 6), varied both within and between collections.

Overall, of the 51 individual pteropod shells analyzed over the five collections, $63 \%$ of the shells exhibited some form of dissolution on the protoconch. There was a pattern of linkage amongst the shell dissolution types. Specifically, among the 51 samples, $14 \%(n=7)$ of shells showed severe dissolution, and all of these also showed moderate dissolution; $29 \%$ ( $n=15)$ of shells showed moderate dissolution as the worst shell condition and all but one of these also showed minor dissolution; $20 \%(n=10)$ of shells exhibited minor dissolution as the worst shell condition. Finally, there were many samples that displayed no signs of shell irregularities. Here, $37 \%(n=19)$ showed no signs of minor, moderate, or severe dissolution.

In terms of gross shell morphometrics, pteropod shells in our collections varied in total protoconch area $\left(7,401 \sim 13,906 \mu \mathrm{m}^{2}\right.$, mean \pm s.d. $\left.=9,387 \pm 2,532 \mu \mathrm{m}^{2}\right)$, but this did not vary

25 significantly between collection days (1-way ANOVA, $\mathrm{p}=0.55$ ). The extent of total dissolution coverage on the protoconch was widely variable as well. While $80 \%(n=41)$ of pteropods exhibited dissolution on less than $50 \%$ of their total protoconch, $0 \%$ of pteropods exhibited moderate and severe dissolution over more than $50 \%$ of their total area.

Shell dissolution classes exhibited variation both within and between collections (Fig. 7). 
dissolution between tows (Kurksal - Wallis test, $p=0.046$ and $p=0.012$, respectively). These differences are largely attributed to Tow 14 , which showed a relatively low undamaged area and relatively high Type 1 area (Dunn test of multiple comparisons, see Fig. 7).

To further compare shell conditions between tows, shells were also classified by the

5 worst dissolution class observed (Fig. 8). Overall, tows were not significantly different when analyzed in this manner (Fisher's Exact Test, $p=0.139$ ). Thus, the variation between tows resides in the ratio of minor dissolution classes rather than in the most severe class of dissolution observed.

\section{Conclusions}

Recently, pteropods have been held up as a potential indicator organism for the biological impacts of ocean acidification because the aragonitic shell is comparatively vulnerable to dissolution. Previous studies that collected animals on cruises and reported a high

15 prevalence of shell dissolution set the stage to link shell abnormalities to exposure to undersaturated seawater with respect to aragonite. The results of this study corroborate this body of earlier work, and shows that some fraction of the collected animals displayed patterns of porosity and corrosion indicative of shell dissolution, although we also collected large numbers of animals with apparently undamaged shells. In addition, the seawater chemistry performed on bottle samples taken simultaneously with the plankton tows indicate that Limacina experienced seawater conditions where saturation state was quite low, although not technically undersaturated $\left(\Omega_{\text {arag }}=1.159 \pm 0.0067\right)$. Overall, our results indicate that a high percentage of this macrozooplankton is experiencing shell loss in situ under present-day carbonate chemistry conditions in the Ross Sea.

Laboratory experiments conducted on this same research project showed that holding Limacina in high $\mathrm{pCO}_{2}(900 \mu \mathrm{atm})$ for 14 days resulted in significant shell dissolution. Although this is not a calibration of dissolution patterns to in situ conditions, it is direct evidence that exposure of live Antarctic pteropods to undersaturated seawater conditions was sufficient to cause shell irregularities (K.M. Johnson, unpublished observation). Previous in situ studies of shell dissolution in Antarctic pteropods found high levels of dissolution across six locations in 
Biogeosciences Discuss., doi:10.5194/bg-2016-467, 2016

Manuscript under review for journal Biogeosciences

Published: 22 November 2016

(c) Author(s) 2016. CC-BY 3.0 License.

the Scotia Sea (Bednaršek et al., 2012). Additional perturbation experiments using pteropods from the Scotia Sea also documented net dissolution when $L$. $h$. antarctica was reared under high $\mathrm{pCO}_{2}$ conditions (Bednaršek et al., 2014b). Similarly, research on Arctic populations of $L$. helicina showed reduced growth rate, dissolution and increased mortality under high $\mathrm{pCO}_{2}$

5 treatments after 28-days (Lishcka et al., 2010).

While the actual exposure conditions or natural events that cause dissolution are still sometimes debated (Bednaršek et al., 2016b;Peck et al., 2015), it is clear from the collections we have made in McMurdo Sound that $L . h$. antarctica experiences conditions in the water column that drive shell dissolution. As a result of the sensitivity of the pteropod shell to

10 carbonate chemistry conditions, pteropod species have been suggested to be sentinel organisms (Roberts et al., 2011;Bednaršek et al., 2016a;Bednaršek and Ohman, 2015). The shell itself is indeed an ideal structure to monitor as it is a thin, aragonitc shell, with multiple layers (SatoOkoshi et al., 2010). Nano-indentation techniques have been developed to test the physical strength and hardness of the L. h. antarctica shell (Teniswood et al., 2013), with the intention of

15 linking shell strength to exposure to undersaturated waters in situ. Further, these nanomaterials techniques were used to compare the shell properties of $L$. $h$. antarctica collections that are almost a decade apart (Teniswood et al., 2016) with some differences being observed. Challenges in the use of Limacina shells as sentinel, bio-recording structures remain because it is not know what carbonate chemistry the pteropods were exposed to in situ prior to collection.

20 Indeed in the present study, more than half the shells we examined displayed shell irregularities, but it is unclear as to what depth or season caused the observed dissolution of juvenile shells.

L. h. antarctica has been the subject of research that examined physiological responses to experimentally altered carbonate chemistry conditions. Previous studies have found that $\mathrm{CO}_{2}$ exposure suppressed metabolism in years when phytoplankton abundance is high, but does not 25 significantly impact metabolism in years of low phytoplankton biomass (Seibel et al., 2012). L. h. antarctica metabolism was also measured in response to low food availability (Maas et al., 2011). Our own studies of juvenile pteropods found that $L$. $h$. antarctica exhibited a differential response to $\mathrm{pCO}_{2}$ only under ambient temperatures $\left(-1.0^{\circ} \mathrm{C}\right)$ (Hoshijima et al., 2016). Specifically, pteropods exposed to the high $\mathrm{pCO}_{2}$ treatment exhibited elevated respiration rates 
Biogeosciences Discuss., doi:10.5194/bg-2016-467, 2016

Manuscript under review for journal Biogeosciences

Published: 22 November 2016

(c) Author(s) 2016. CC-BY 3.0 License.

relative to those exposed to low $\mathrm{pCO}_{2}$ conditions. However, this $\mathrm{pCO}_{2}$ treatment effect was not evident when pteropods experienced elevated $\mathrm{pCO}_{2}$ at an elevated temperature of $+4{ }^{\circ} \mathrm{C}$.

Recent research focused on the impacts of ocean acidification on other Antarctic marine invertebrates, in general, has shown a range of responses, with most of the described responses

5 being deleterious. For other members of the zooplankton, laboratory studies have shown that early stage krill (Euphausia superba) are sensitive to high $\mathrm{pCO}_{2}$ levels (Kawaguchi et al., 2011). Risk maps based upon the sensitivity of krill egg hatching success have also been developed for regions of the Southern Ocean (Kawaguchi et al., 2013) and suggest that high-risk areas for krill will develop in regions such as the Weddell Sea. Similarly, studies on adult forms of E. superba

10 have measured metabolic changes that indicate elevated $\mathrm{pCO}_{2}$ induced a cost to maintenance (Saba et al., 2012). Data on Antarctic benthic marine invertebrates show similar responses. For example, a 6-week study on the effects of ocean acidification and temperature on adult Antarctic limpets, Nacella concinna, and snails, Margarella antarctica, found negligible impacts on M. antarctica and a small decrease in gonadal lipid content in N. concinna (Schram et al.,

15 2016). Taken together these results suggest Antarctic benthic invertebrates may have a significant level of resistance to changes in $\mathrm{pH}$.

Overall, these responses are critical in light of recent projections regarding Southern Ocean carbonate chemistry that suggest that by 2050, surface waters will be undersaturated with respect to aragonite for multiple months each year and will reach close to yearlong undersaturation by 2100 (Hauri et al., 2015) and seasonal undersaturation will be an issue even sooner (Kapsenberg et al., 2015). These projections, coupled with research into the contemporary carbonate system in the Southern Ocean have highlighted the extent to which undersaturation events are occurring and will occur in the future.

The observed levels of dissolution found in this study adds to the growing body of evidence that find contemporary shell dissolution in the globally distributed pteropod, $L$. helicina. This pattern raises important questions as to the effect dissolution has on organismal performance, fitness and future viability. In addition, the risk to populations of pteropods will be defined by the impacts of OA on reproductive success. Although we have little information about how variable carbonate chemistry influences early development in situ, laboratory studies have shown that exposure to high $\mathrm{pCO}_{2}$ levels can lead to decreases in egg densities in gravid 
Biogeosciences Discuss., doi:10.5194/bg-2016-467, 2016

Manuscript under review for journal Biogeosciences

Published: 22 November 2016

(c) Author(s) 2016. CC-BY 3.0 License.

females with up to $80 \%$ of those eggs failing to successfully develop into larvae (Manno et al., 2016). These results highlight the need for further research into how $L$. $h$. antarctica and other key macrozooplankton species will fare in response to multiple stressors in the Southern Ocean.

\section{Data availability}

Following publication, Dryad (http://datadryad.org/) will be used as a repository for the organismal and carbonate chemistry data in this study.

\section{Author contributions}

$\mathrm{KMJ}, \mathrm{OH}$, and $\mathrm{GEH}$ conducted the fieldwork (plankton tows and water sampling), and processed samples at McMurdo Station. OH and KMJ performed carbonate chemistry measurements and calculations. KMJ, ATN and CSS performed the scanning electron microscopy; CSS and OH performed the analysis of the SEM data. Finally, all authors contributed to writing the manuscript.

\section{Competing interests}

The authors declare that they have no conflict of interest.

\section{Acknowledgements}

The authors would like to thank members of the U.S. Antarctic Program and Lockheed Martin's Antarctic Support Corporation (ASC) for support at McMurdo Station, Antarctica during the 2014-2015 Summer Field Season. In addition, we thank Professor Mary Sewell (University of Auckland) for the loan of the collapsible plankton net, and Mr. Carl Reim (Polar Geospatial Center, University of Minnesota) for preparing the map of our study sites. This research was

25 supported by a grant from the U.S. National Science Foundation (NSF) through the U.S. Antarctic Program (PLR-1246202 to GEH). During the course of this project, Kevin Johnson and Umihiko Hoshijima were each supported by an NSF Graduate Research Fellowship. The MRL Shared Experimental Facilities are supported by the MRSEC Program of the NSF under Award No. DMR 1121053; a member of the NSF-funded Materials Research Facilities Network (www.mrfn.org). 
Biogeosciences Discuss., doi:10.5194/bg-2016-467, 2016

Manuscript under review for journal Biogeosciences

Published: 22 November 2016

(c) Author(s) 2016. CC-BY 3.0 License.

\section{References}

Andersson, A. J., Mackenzie, F. T., and Bates, N. R.: Life on the margin: implications of ocean acidification on Mg-calcite, high latitude and cold-water marine calcifiers, Marine Ecology Progress Series, 373, 265-273, 2008.

Bednaršek, N., Tarling, G. A., Bakker, D. C. E., Fielding, S., Jones, E. M., Venables, H. J., Ward, P., Kuzirian, A., Leze, B., Feely, R. A., and Murphy, E. J.: Extensive dissolution of live pteropods in the Southern Ocean, Nat Geosci, 5, 881-885, Doi 10.1038/Ngeo1635, 2012.

Bednaršek, N., Tarling, G., Fielding, S., and Bakker, D.: Population dynamics and biogeochemical significance of Limacina helicina antarctica in the Scotia Sea (Southern Ocean), Deep Sea Research Part II: Topical Studies in Oceanography, 59, 105-116, 2012a.

Bednaršek, N., Tarling, G. A., Bakker, D. C., Fielding, S., Cohen, A., Kuzirian, A., McCorkle, D., Lézé, B., and Montagna, R.: Description and quantification of pteropod shell dissolution: a sensitive bioindicator of ocean acidification, Glob. Change Biol., 18, 2378-2388, 2012b.

Bednaršek, N., Tarling, G. A., Bakker, D. C. E., Fielding, S., Jones, E. M., Venables, H. J., Ward, P., Kuzirian, A., Leze, B., Feely, R. A., and Murphy, E. J.: Extensive dissolution of live pteropods in the Southern Ocean, Nat Geosci, 5, 881-885, Doi 10.1038/Ngeo1635, 2012c.

Bednaršek, N., Feely, R. A., Reum, J. C. P., Peterson, B., Menkel, J., Alin, S. R., and Hales, B.: Limacina helicina shell dissolution as an indicator of declining habitat suitability owing to ocean acidification in the California Current Ecosystem, Proceedings of the Royal Society of London B: Biological Sciences, 281, 2014a.

Bednaršek, N., Tarling, G. A., Bakker, D. C. E., Fielding, S., and Feely, R. A.: Dissolution dominating calcification process in polar pteropods close to the point of aragonite undersaturation, PLoS One, 9, 10.1371/journal.pone.0109183, 2014b.

Bednaršek, N., and Ohman, M. D.: Changes in pteropod distributions and shell dissolution across a frontal system in the California Current System, Marine Ecology Progress Series, 523, 93-103, 2015.

Bednaršek, N., Harvey, C. J., Kaplan, I. C., Feely, R. A., and Možina, J.: Pteropods on the edge: Cumulative effects of ocean acidification, warming, and deoxygenation, Progress in Oceanography, 145, 1-24, http://dx.doi.org/10.1016/j.pocean.2016.04.002, 2016a.

Bednaršek, N., Johnson, J., and Feely, R. A.: Vulnerability of pteropod (Limacina helicina) to ocean acidification: shell dissolution occurs despite an intact organic layer, Deep Sea Research Part II: Topical Studies in Oceanography, 2016b.

Comeau, S., Gorsky, G., Jeffree, R., and Gattuso, J.-P.: Impact of ocean acidification on a key Arctic pelagic mollusc (Limacina helicina), Biogeosciences, 6, 1877-1882, doi:10.5194/bg-6-1877-2009, 2009.

Dickson, A. G., Sabine, C. L., and Christian, J. R.: Guide to best practices for ocean $\mathrm{CO}_{2}$ measurements, PICES Special Publication, 3, 191 pp., 2007.

Fabry, V. J.: Aragonite production by pteropod molluscs in the subarctic Pacific, Deep Sea Research, 36, 1735-1751, 1989. 
Biogeosciences Discuss., doi:10.5194/bg-2016-467, 2016

Manuscript under review for journal Biogeosciences

Published: 22 November 2016

(c) Author(s) 2016. CC-BY 3.0 License.

Fabry, V. J., Seibel, B. A., Feely, R. A., and Orr, J. C.: Impacts of ocean acidification on marine fauna and ecosystem processes, Ices Journal of Marine Science, 65, 414-432, 10.1093/icesjms/fsn048, 2008.

Fabry, V. J., McClintock, J. B., Mathis, J. T., and Grebmeier, J. M.: Ocean acidification at high latitudes: The bellweather, Oceanography, 22, 160-171, 2009.

Feely, R. A., Sabine, C. L., Lee, K., Berelson, W., Kleypas, J., Fabry, V. J., and Millero, F. J.: Impact of Anthropogenic $\mathrm{CO}_{2}$ on the $\mathrm{CaCO}_{3}$ System in the Oceans, Science, 305, 362366, 2004.

Hauri, C., Friedrich, T., and Timmermann, A.: Abrupt onset and prolongation of aragonite undersaturation events in the Southern Ocean, Nature Climate Change, doi:10.1038/nclimate2844, 2015.

Hofmann, G. E., Barry, J. P., Edmunds, P. J., Gates, R. D., Hutchins, D. A., Klinger, T., and Sewell, M. A.: The Effect of Ocean Acidification on Calcifying Organisms in Marine Ecosystems: An Organism-to-Ecosystem Perspective, Annual Review of Ecology, Evolution, and Systematics, 41, 127-147, doi:10.1146/annurev.ecolsys.110308.120227, 2010.

Hoshijima, U., Wong, J. M., and Hofmann, G. E.: Metabolic rate changes under variable $\mathrm{pCO}_{2}$ and temperature in the Antarctic pteropod Limacina helicina antarctica, J. Exp. Biol., 2016.

20 Hunt, B. P. V., Pakhomov, E. A., Hosie, G. W., Siegel, V., Ward, P., and Bernard, K.: Pteropods in Southern Ocean ecosystems, Progress in Oceanography, 78, 193-221, 10.1016/j.pocean.2008.06.001, 2008.

Kapsenberg, L., Kelley, A. L., Shaw, E. C., Martz, T. R., and Hofmann, G. E.: Near-shore Antarctic $\mathrm{pH}$ variability has implications for the design of ocean acidification experiments, Sci Rep, 5, 9638, 10.1038/srep09638, 2015.

Kawaguchi, S., Kurihara, H., King, R., Hale, L., Berli, T., Robinson, J. P., Ishida, A., Wakita, M., Virtue, P., Nicol, S., and Ishimatsu, A.: Will krill fare well under Southern Ocean acidification?, Biol Lett, 7, 288-291, 10.1098/rsbl.2010.0777, 2011.

Kawaguchi, S., Ishida, A., King, R., Raymond, B., Waller, N., Constable, A., Nicol, S., Wakita, M., and Ishimatsu, A.: Risk maps for Antarctic krill under projected Southern Ocean acidification, Nature Climate Change, 3, 843-847, doi:10.1038/nclimate1937, 2013.

Lischka, S., Büdenbender, J., Boxhammer, T., and Leibniz-Riebesel, U.: Impact of ocean acidification and elevated temperatures on early juveniles of the polar shelled pteropod Limacina helicina: mortality, shell degradation, and shell growth, Biogeosciences, 8, 919932, doi:10.5194/bg-8-919-2011, 2011.

Maas, A. E., Elder, L. E., Dierssen, H. M., and Seibel, B. A.: Metabolic response of Antarctic pteropods (Mollusca: Gastropoda) to food deprivation and regional productivity, Marine Ecology Progress Series, 441, 129-139, 2011.

Manno, C., Peck, V. L., and Tarling, G. A.: Pteropod eggs released at high $\mathrm{pCO}_{2}$ lack resilience to ocean acidification, Scientific Reports, 6, doi:10.1038/srep25752, 2016.

McNeil, B. I., and Matear, R. J.: Southern Ocean acidification: A tipping point at 450-ppm atmospheric $\mathrm{CO}_{2}$, Proceedings of the National Academy of Sciences, 105, 18860-18864, 2008. 
Biogeosciences Discuss., doi:10.5194/bg-2016-467, 2016

Manuscript under review for journal Biogeosciences

Published: 22 November 2016

(c) Author(s) 2016. CC-BY 3.0 License.

Orr, J. C., Fabry, V. J., Aumont, O., Bopp, L., Doney, S. C., Feely, R. A., Gnanadesikan, A., Gruber, N., Ishida, A., Joos, F., Key, R. M., Lindsay, K., Maier-Reimer, E., Matear, R., Monfray, P., Mouchet, A., Najjar, R. G., Plattner, G.-K., Rodgers, K. B., Sabine, C. L., Sarmiento, J. L., Schlitzer, R., Slater, R. D., Totterdell, I. J., Weirig, M.-F., Yamanaka, Y., and Yool, A.: Anthropogenic ocean acidification over the twenty-first century and its impact on calcifying organisms, Nature, 437, 681, 2005.

Peck, V. L., Tarling, G. A., Manno, C., Harper, E., and Tynan, E.: Outer organic layer and internal repair mechanism protects pteropod Limacina helicina from ocean acidification, Deep Sea Research II., 10.1016/j.dsr2.2015.12.005, 2015.

Robbins, L. L., Hansen, M. E., Kleypas, J. A., and Meylan, S. C.: CO2calc-A user-friendly seawater carbon calculator for Windows, Max OS X, and iOS (iPhone), 2010.

Roberts, D., Howard, W. R., Moy, A. D., Roberts, J. L., Trull, T. W., Bray, S. G., and Hopcroft, R. R.: Interannual pteropod variability in sediment traps deployed above and below the aragonite saturation horizon in the Sub-Antarctic Southern Ocean, Polar Biology, 34, 1739-1750, 10.1007/s00300-011-1024-z, 2011.

Saba, G. K., Schofield, O., Torres, J. J., Ombres, E. H., and Steinberg, D. K.: Increased Feeding and Nutrient Excretion of Adult Antarctic Krill, Euphausia superba Exposed to Enhanced Carbon Dioxide $\left(\mathrm{CO}_{2}\right)$, PLoS ONE, 7, e52224, 10.1371/journal.pone.0052224, 2012.

Sato-Okoshi, W., Okoshi, K., Sasaki, H., and Akiha, F.: Shell structure characteristics of pelagic and benthic molluscs from Antarctic waters, Polar Science, 4, 10.1016/j.polar.2010.05.006, 2010.

Schram, J. B., Schoenrock, K. M., McClintock, J. B., Amsler, C. D., and Angus, R. A.: Testing Antarctic resilience: the effects of elevated seawater temperature and decreased $\mathrm{pH}$ on two gastropod species, ICES J. Mar. Sci., 73, 529-536, 10.1093/icesjms/fsv233, 2016.

Schram, J. B. S., Kathryn M. McClintock, James B. Amsler, Charles D. Angus, Robert A.: Multi-frequency observations of seawater carbonate chemistry on the central coast of the western Antarctic Peninsula, Polar Res., 34, http://dx.doi.org/10.3402/polar.v34.25582, 2015.

Seibel, B. A., Maas, A. E., and Dierssen, H. M.: Energetic plasticity underlies a variable response to ocean acidification in the pteropod, Limacina helicina antarctica, PLoS One, 7, e30464, 10.1371/journal.pone.0030464, 2012.

Sewell, M. A.: Examination of the meroplankton community in the south-western Ross Sea, Antarctica, using a collapsible plankton net, Polar Biology, 28, 119-131, 10.1007/s00300-004-0670-9, 2005.

35 Teniswood, C. M. H., Roberts, D., Howard, W. R., and Bradby, J. E.: A quantitative assessment of the mechanical strength of the polar pteropod Limacina helicina antarctica shell, ICES Journal of Marine Science: Journal du Conseil, 70, 1499-1505, 10.1093/icesjms/fst100, 2013.

Teniswood, C. M. H., Roberts, D., Howard, W. R., Bray, S. G., and Bradby, J. E.: Microstructural shell strength of the Subantarctic pteropod Limacina helicina antarctica, Polar Biology, 39, 1643-1652, 10.1007/s00300-016-1888-z, 2016. 
5 Table 1: Carbonate chemistry parameters calculated from field-collected seawater sample. The concentration of $\mathrm{CO}_{2}\left(p \mathrm{CO}_{2}\right)$, as well as the aragonite saturation state $\left(\Omega_{\text {aragonite }}\right)$ was derived from measured $\mathrm{pH}$ in the total scale $\left(\mathrm{pH}_{\mathrm{T}}\right)$, measured total alkalinity $(\mathrm{TA})$, and measured salinity at a constant temperature of $-1.9^{\circ} \mathrm{C}$ (see Methods).

\begin{tabular}{cccccc}
\hline Date & $\mathrm{pH}_{\mathrm{T}}$ & $\mathrm{pCO}_{2}(\mu \mathrm{atm})$ & $\Omega_{\text {aragonite }}$ & $\mathrm{TA}\left(\right.$ umol I $\left.^{-1}\right)$ & Salinity \\
\hline $10 / 31$ & $7.988 \pm 0.003$ & $452.1 \pm 2.6$ & $1.159 \pm 0.006$ & 2344.33 & 34.0 \\
$11 / 4$ & $7.996 \pm 0.003$ & $444.1 \pm 10.6$ & $1.179 \pm 0.023$ & 2358.09 & 34.3 \\
$11 / 8$ & $7.988 \pm 0.006$ & $456.6 \pm 3.2$ & $1.175 \pm 0.007$ & 2353.35 & 34.3 \\
$11 / 11$ & $7.992 \pm 0.005$ & $449.8 \pm 3.3$ & $1.182 \pm 0.007$ & 2353.61 & 34.3 \\
$11 / 15$ & $8.001 \pm 0.003$ & $438.2 \pm 5.7$ & $1.204 \pm 0.013$ & 2351.33 & 34.3 \\
$11 / 17$ & $7.995 \pm 0.000$ & $445.1 \pm 5.8$ & $1.188 \pm 0.013$ & 2354.77 & 34.2 \\
$11 / 18$ & $8.004 \pm 0.004$ & $435.3 \pm 2.8$ & $1.208 \pm 0.006$ & 2348.35 & 34.3 \\
$11 / 22$ & $7.992 \pm 0.002$ & $449.3 \pm 0.2$ & $1.178 \pm 0.001$ & 2351.28 & 34.2 \\
$11 / 24$ & $8.010 \pm 0.009$ & $428.2 \pm 3.6$ & $1.222 \pm 0.009$ & 2347.16 & 34.0 \\
$11 / 28$ & $8.009 \pm 0.003$ & $429.9 \pm 2.4$ & $1.22 \pm 0.006$ & 2368.73 & 34.2 \\
$12 / 1$ & $8.010 \pm 0.001$ & $429.3 \pm 1.2$ & $1.224 \pm 0.003$ & 2354.27 & 34.2 \\
$12 / 3$ & $8.027 \pm 0.004$ & $411.2 \pm 3.5$ & $1.263 \pm 0.009$ & 2350.55 & 34.1 \\
$12 / 5$ & $8.029 \pm 0.003$ & $410.7 \pm 2.9$ & $1.271 \pm 0.008$ & 2358.88 & 34.0 \\
$12 / 8$ & $8.016 \pm 0.001$ & $424.9 \pm 0.6$ & $1.239 \pm 0.002$ & 2363.20 & 34.0 \\
\hline
\end{tabular}


Biogeosciences Discuss., doi:10.5194/bg-2016-467, 2016

Manuscript under review for journal Biogeosciences

Published: 22 November 2016

(c) Author(s) 2016. CC-BY 3.0 License.

\section{Figure captions}

Figure 1: Map of study site in McMurdo Sound, Antarctica. The map, based upon satellite images, shows the U.S. research station, McMurdo Sound (blue symbol), and the sampling

5 station near Cape Royds (red symbol). Mapping data are courtesy of the Scientific Committee on Antarctic Research, Antarctic Digital Database using True-color (bands 2-2-3) Landsat 8 OLI imagery from United States Geological Survey.

Figure 2: Stereomicroscope image of a live pteropod (Limacina helicina antarctica) illustrating determination of shell size. The image was obtained with a Wild M37Z stereomicroscope at a magnification of 150X. The white line shown across the shell indicates the manner in which shell size was determined.

Figure 3: Collection densities of Limacina helicina antarctica over the 6-week collection

15 period. Pteropods were collected using a small, collapsible plankton net (100 um mesh) towed by hand to a depth of $50 \mathrm{~m}$ and retrieved at approximately $2.4 \mathrm{~m} \mathrm{~s}^{-1}$ (approximately $2 \mathrm{~min}$ per tow). Bars indicate average density (Individuals $\mathrm{m}^{-3}$ ) calculated as total number of pteropods over the total volume of water sampled. Error bars indicate standard error of the mean.

20 Figure 4: Shell diameters of Limacina helicina antarctica throughout the collection period. Overall the diameter increased over time with a new size class appearing approximately every two weeks. Size classes were defined as values sharing the same letter $(a, b, c)$ that were not significantly different from each other after Tukey's honestly significant difference (HSD) test (adjusted p-value <0.05). Size class $1(0.84 \pm 0.09 \mathrm{~mm})$ first appeared October 31st and ended

25 November $11^{\text {th }}$, size class $2(1.01 \pm 0.15 \mathrm{~mm})$ lasted from November $15^{\text {th }}-$ November $22^{\text {nd }}$ and size class $3(1.19 \pm 0.14 \mathrm{~mm})$ lasted from November $24^{\text {th }}-$ December $8^{\text {th }}$. Error bars indicate standard error of the mean. 
Biogeosciences Discuss., doi:10.5194/bg-2016-467, 2016

Manuscript under review for journal Biogeosciences

Published: 22 November 2016

(c) Author(s) 2016. CC-BY 3.0 License.

Figure 5: In situ carbonate chemistry measurements from October $31^{\text {st }}-$ December $8^{\text {th }}$. There was no significant change in carbonate chemistry throughout the collection period; however, a general trend of decreasing $\mathrm{pCO}_{2}$ concentration is visible.

5 Figure 6: Representative shell conditions of Limacina helicina antarctica. (a-c) Paired light microscope and SEM images of a pristine specimen displaying a fully translucent shell with no discernible areas of dissolution (i.e., Type 0). (d-f) Paired light microscope and SEM images of a shell exhibiting a mosaic of dissolution types across an opaque protoconch. (g) Closer examination of the intact upper prismatic layer and microsculpture of the protoconch shown in

10 (c). (h-i) Higher magnification images of ( $\mathbf{f}$ ) providing examples of each type of shell dissolution as indicated by the arrows and numbers. Type I = minor intracrystalline porosity in the upper prismatic layer; Type II = substantial intracrystalline porosity with some missing patches of aragonite crystals from the upper prismatic layer; and Type III = the upper prismatic layer is absent thus exposing the arrays of interdigitated aragonite crystals that compose the underlying

15 crossed-lamellar layer.

Figure 7: Percent of shell area displaying each dissolution type. Data shown list dissolution type $(0,1,2,3)$ as analyzed for each tow (tow's 2, 7, 9 and 14). Each tow is presented using stacked bar plots, while each individual bar represents an individual shell with colors corresponding each of the 4 dissolution types.

Figure 8: Individuals counted based on the worst level of dissolution visible on the protoconch for each collection date. While Type 0 (No dissolution) is most prominent throughout the collection period, Type 3 (Severe) dissolution was present in all but the final collection. 
Biogeosciences Discuss., doi:10.5194/bg-2016-467, 2016

Manuscript under review for journal Biogeosciences

Published: 22 November 2016

(c) Author(s) 2016. CC-BY 3.0 License.

(c) (1)

Figure 1: Map of study site in McMurdo Sound, Antarctica.

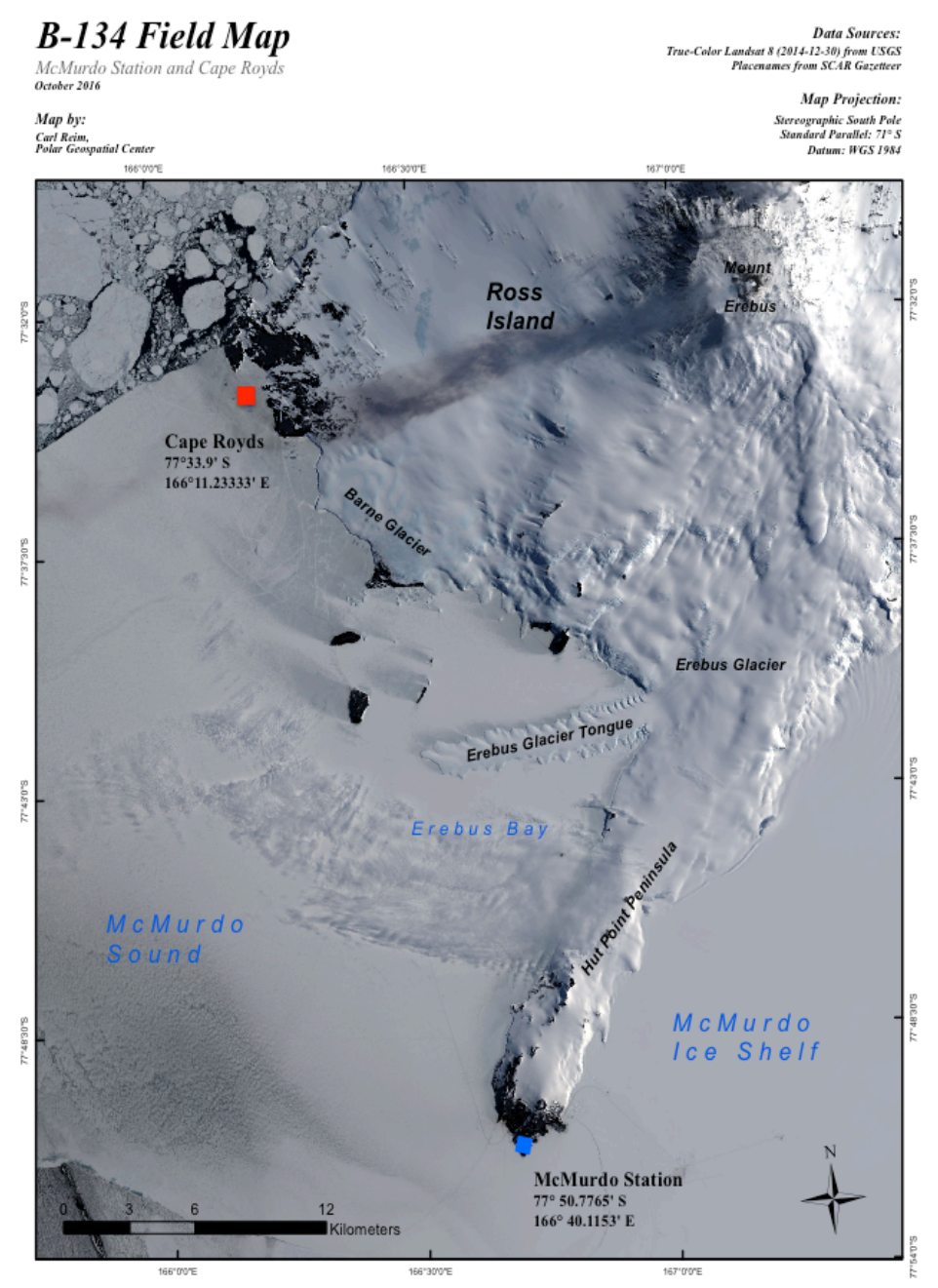


Biogeosciences Discuss., doi:10.5194/bg-2016-467, 2016

Manuscript under review for journal Biogeosciences

Published: 22 November 2016

(c) Author(s) 2016. CC-BY 3.0 License.

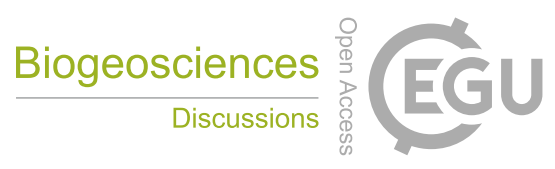

Figure 2: Stereomicroscope image of a live pteropod (Limacina helicina antarctica) illustrating determination of shell size.

5

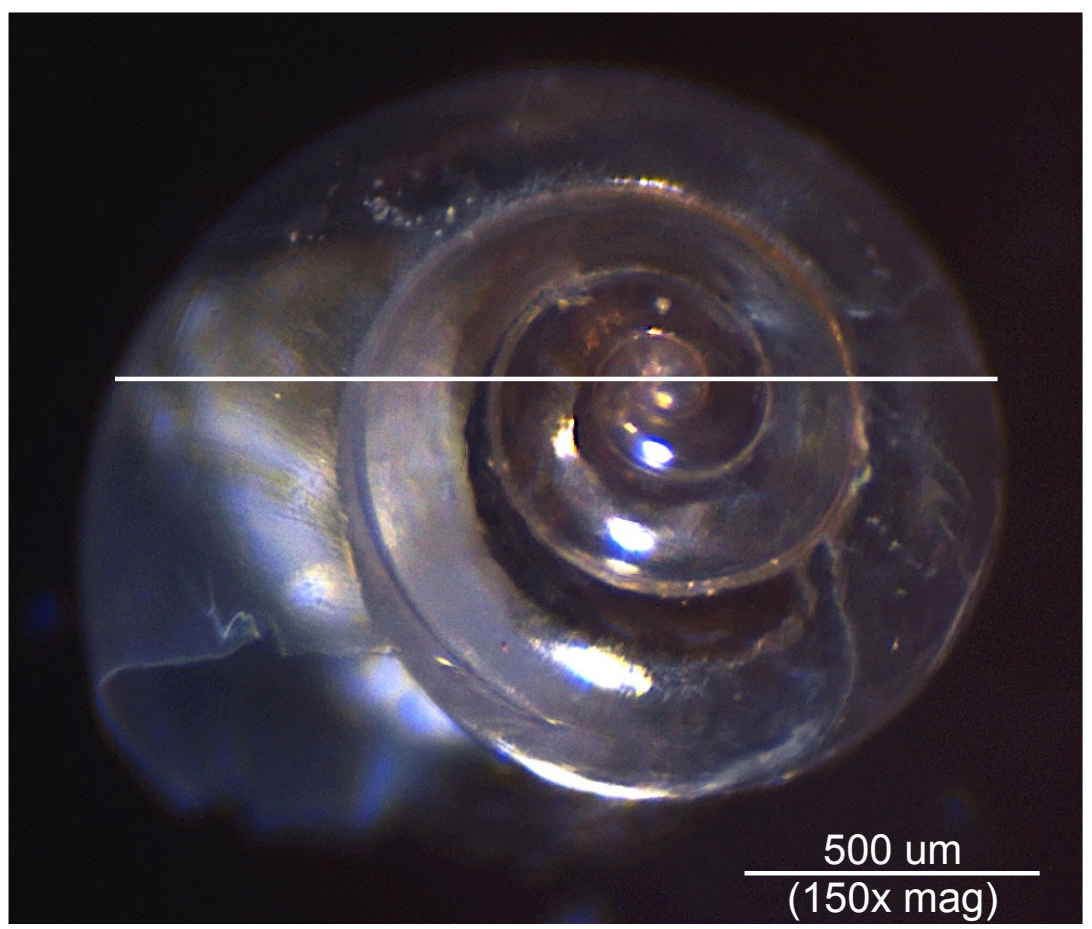


Figure 3: Collection densities of Limacina helicina antarctica over the 6-week collection period.

5

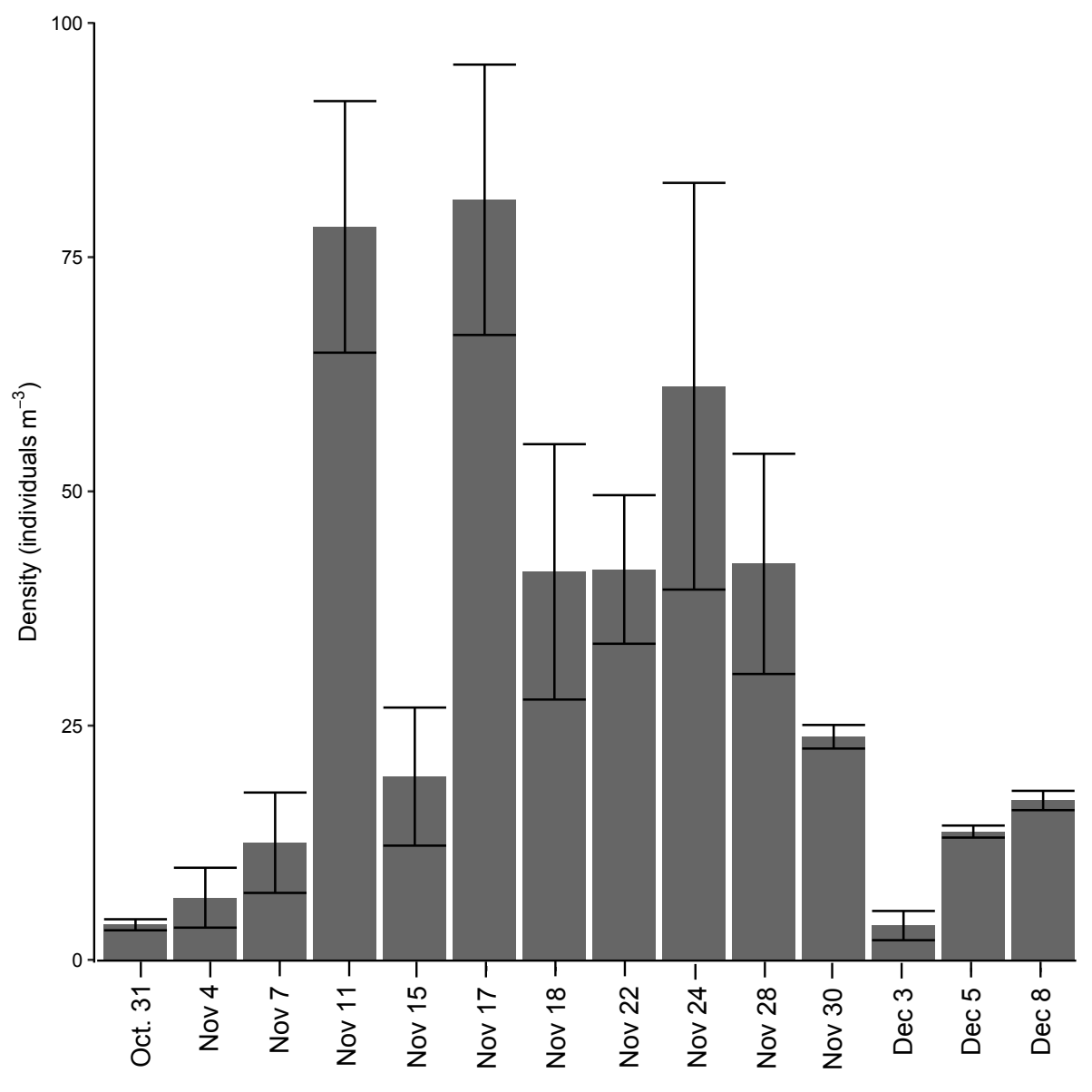


Biogeosciences Discuss., doi:10.5194/bg-2016-467, 2016

Manuscript under review for journal Biogeosciences

Published: 22 November 2016

(c) Author(s) 2016. CC-BY 3.0 License.

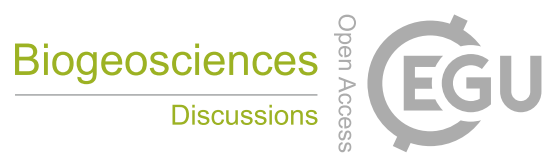

(c) (i)

Figure 4: Shell diameters of Limacina helicina antarctica throughout the collection period.

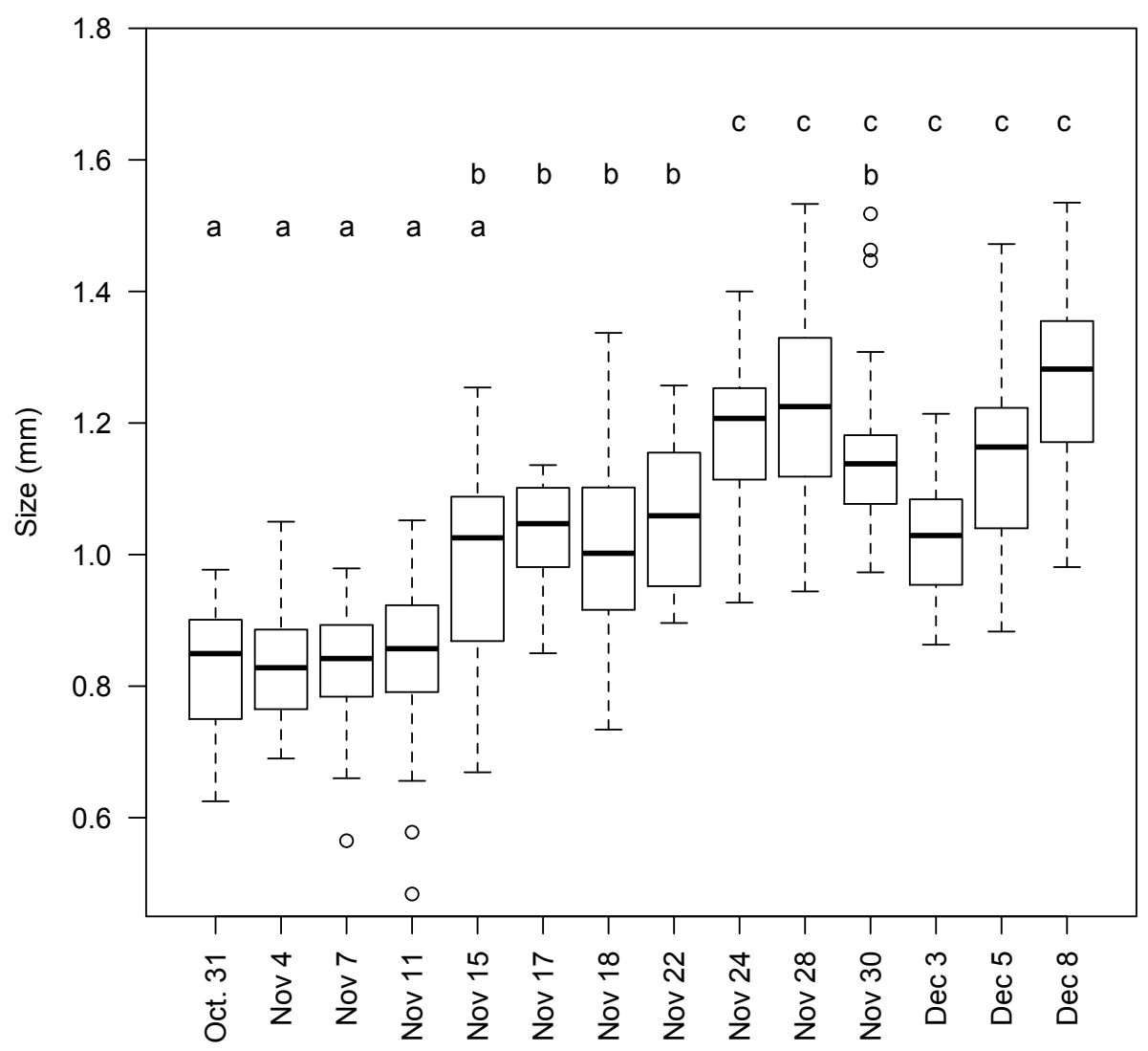

5 
Biogeosciences Discuss., doi:10.5194/bg-2016-467, 2016

Manuscript under review for journal Biogeosciences

Published: 22 November 2016

(c) Author(s) 2016. CC-BY 3.0 License.

Figure 5: In situ carbonate chemistry measurements from October $31^{\text {st }}-$ December $8^{\text {th }}$.
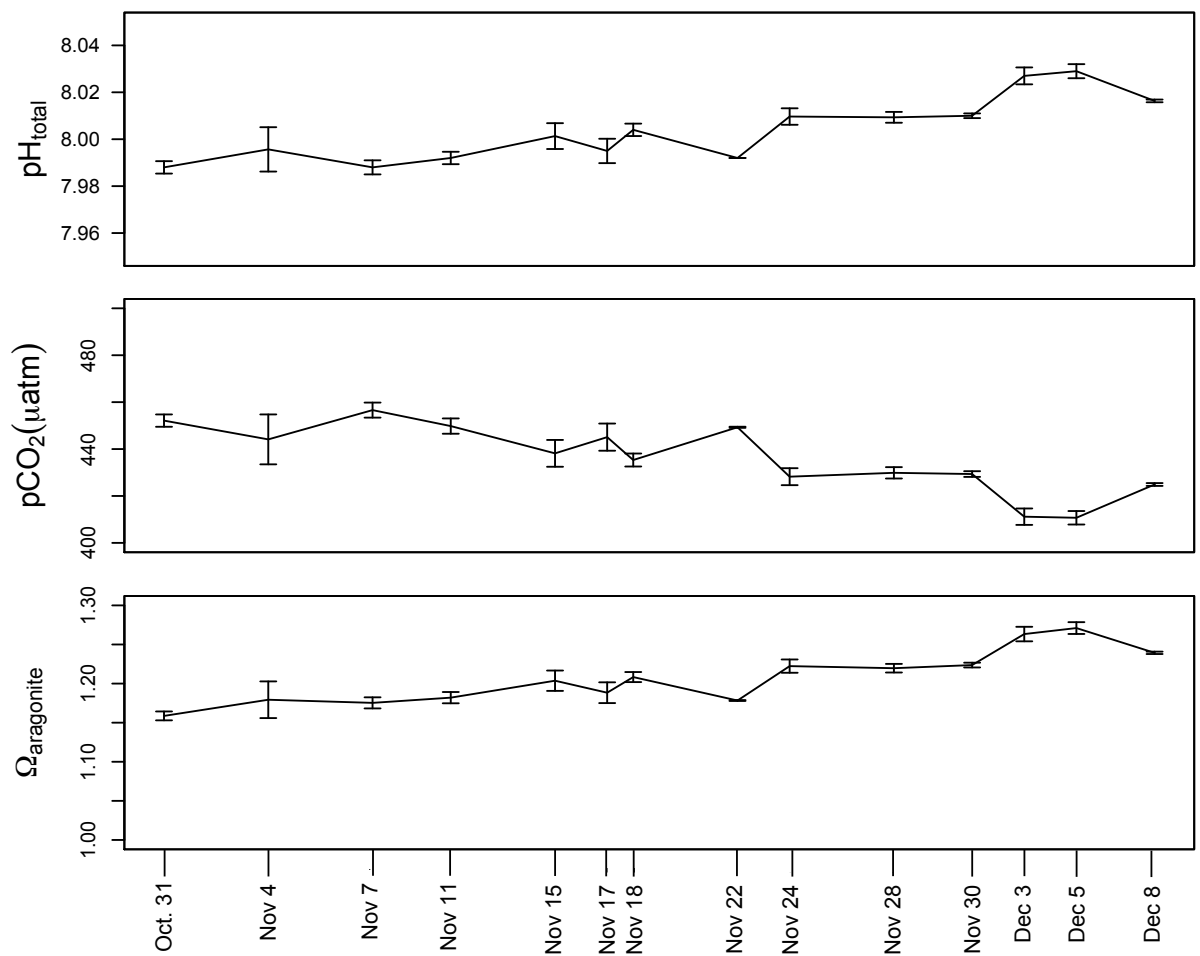

5 
Biogeosciences Discuss., doi:10.5194/bg-2016-467, 2016

Manuscript under review for journal Biogeosciences

Published: 22 November 2016

(c) Author(s) 2016. CC-BY 3.0 License.

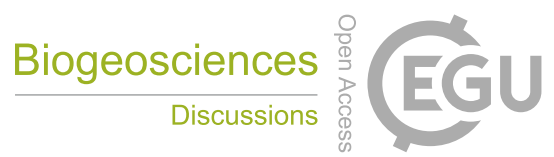

Figure 6: Representative shell conditions of Limacina helicina antarctica.
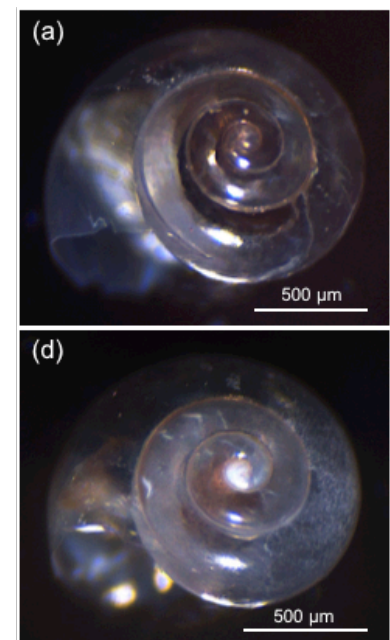

5
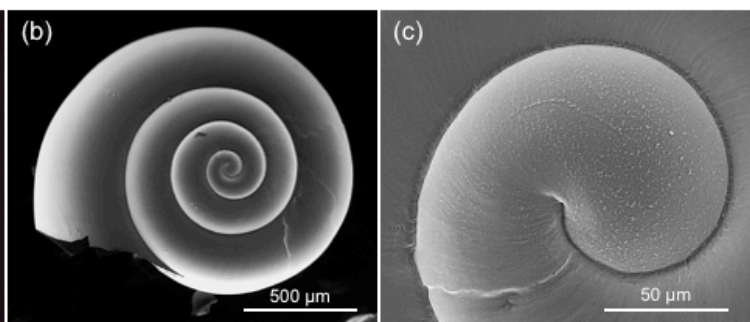

(e)
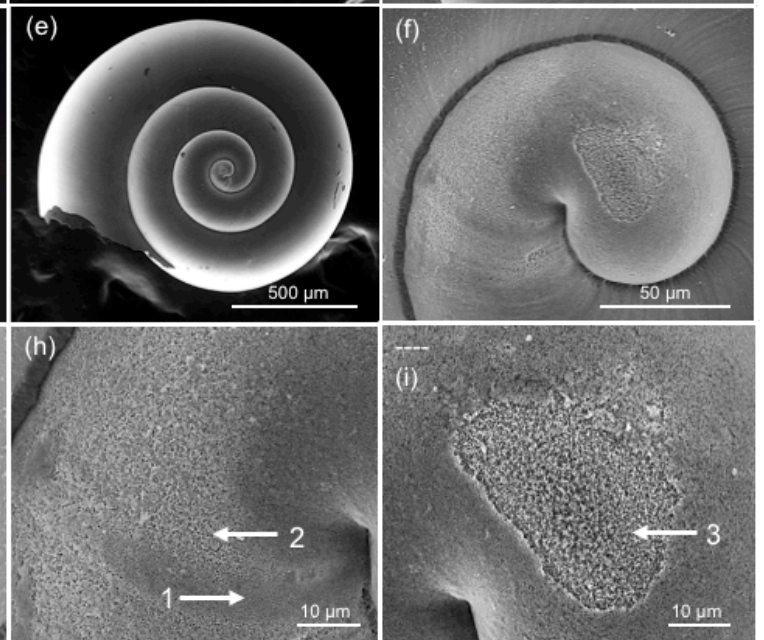
Biogeosciences Discuss., doi:10.5194/bg-2016-467, 2016

Manuscript under review for journal Biogeosciences

Published: 22 November 2016

(c) Author(s) 2016. CC-BY 3.0 License.

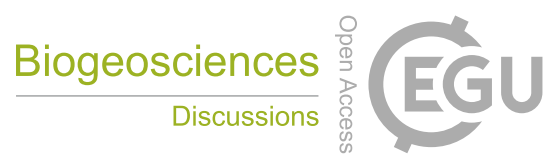

(c) $\underset{\mathrm{BY}}{(i)}$

Figure 7: Percent of shell area displaying each dissolution type.

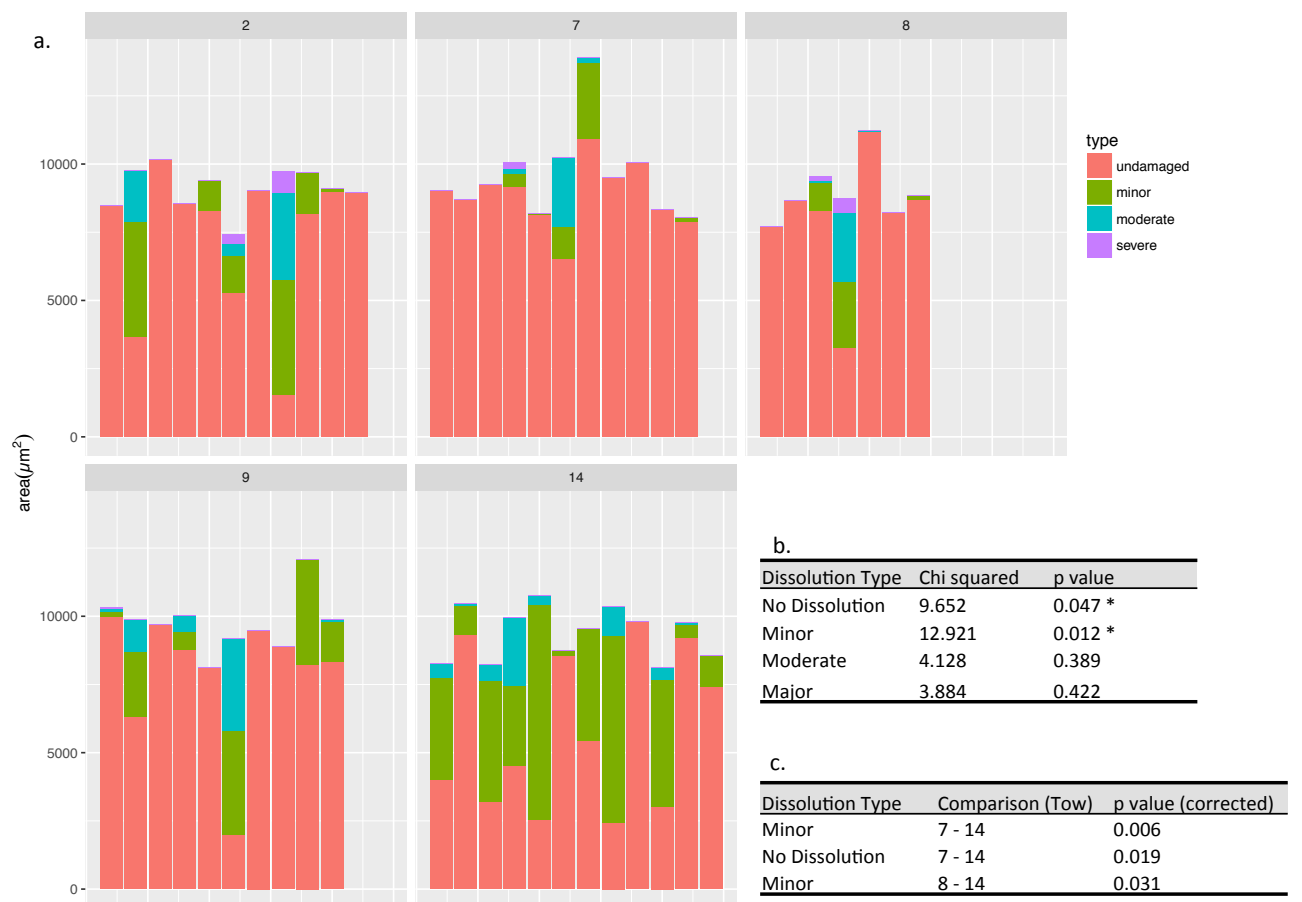

5 
Biogeosciences Discuss., doi:10.5194/bg-2016-467, 2016

Manuscript under review for journal Biogeosciences

Published: 22 November 2016

(c) Author(s) 2016. CC-BY 3.0 License.

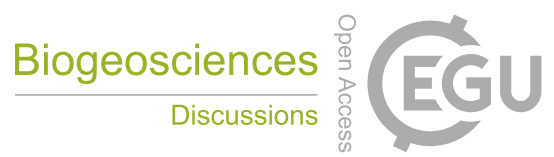

(c) (i)

Figure 8: Individuals counted based on the worst level of dissolution visible on the protoconch for each collection date.

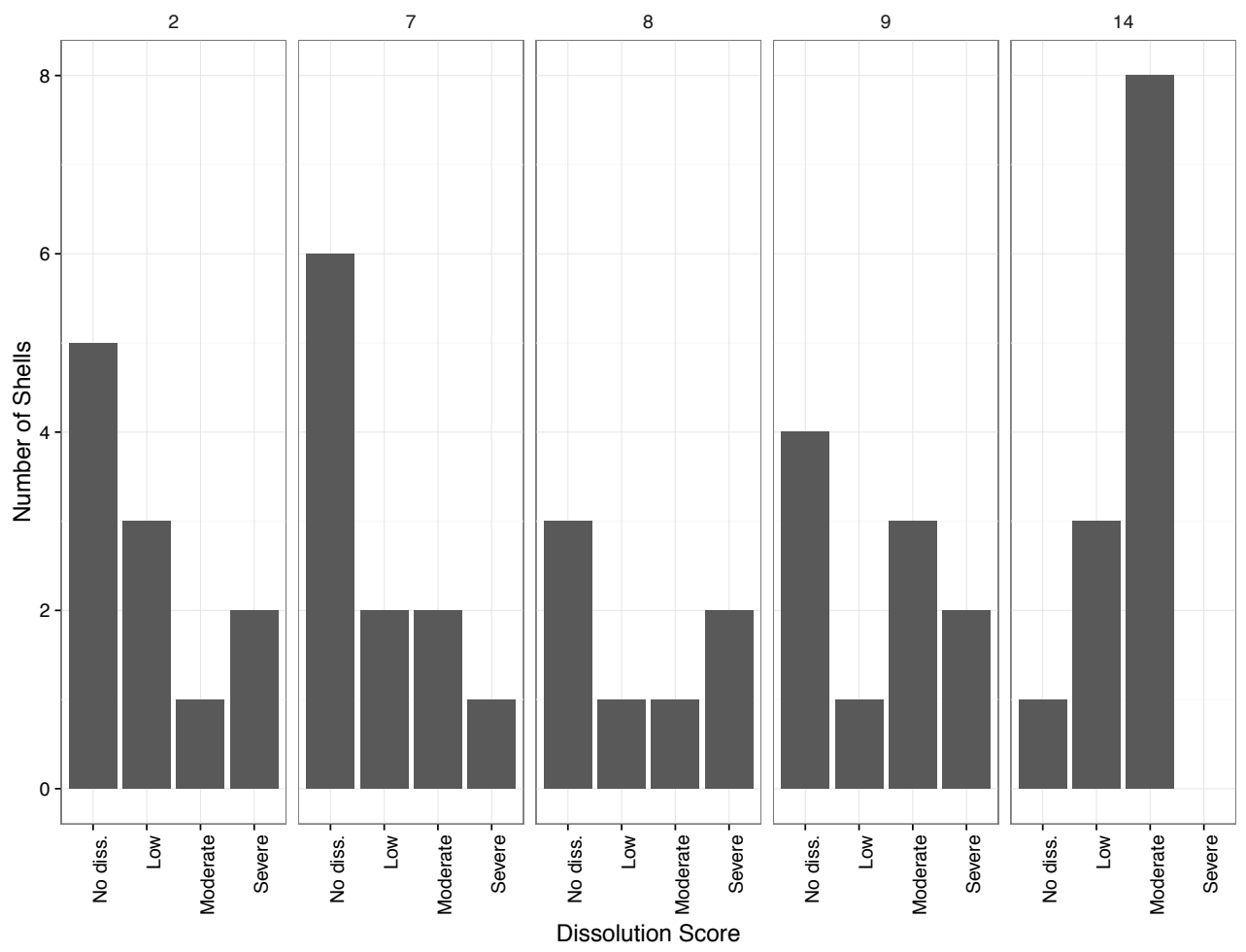

5 